\title{
Influence of the Hydrophobicity and Surface Roughness of Pears on the Adhesion of Salmonella Enterica Enteritidis and Escherichia Coli
}

Jackline Freitas Brilhante De São José (I), Hiasmyne Silva Medeiros (III), Patrícia Campos Bernardes (II), Leonardo Faria Silva (III), Nélio José De Andrade (III)

(I) UFES - Universidade Federal do Espírito Santo (Avenida Marechal Campos, Maruípe, Vitória-ES), (II) UFES - Universidade Federal do Espírito Santo (Centro de Ciências Agrárias, Alegre-ES), (III) UFV - Universidade Federal de Viçosa (Av. P.H.Rolfs, s/n,

\section{Resumo}

The adhesion of bacteria to surfaces has been a problem for food safety. The aim was to examine surface hydrophobicity and roughness of pear on the adherence process of Salmonella Enteritidis and Escherichia coli .The contact angles between the surface and water,formamide and $\alpha$ bromonaphthalene were determined using a goniometer. Measuring the contact angle on the surfaces of S. Enteritidis and E. coli cells was performed on a layer of vegetative cells. The roughness of the surfaces were evaluated using a profilometer and was expressed in micrometers $(\mu \mathrm{m})$.Pears (Pyrus communis L.) were acquired from local retailers. A suspension of S. Enteritidis (ATCC 13076) and Escherichia coli (ATCC $11229)$ vegetative cells was utilized. Suspensions were prepared containing approximately $10^{7} \mathrm{CFU} / \mathrm{mL}$ of each bacteria.Pears were intentionally contaminated with each bacteria separately. After incubation at $25^{\circ} \mathrm{C}$ for 24 $\mathrm{h}$, slices $(1.0 \times 1.0 \mathrm{~cm})$ were aseptically cut using a scalpel, and the number of adherent cells was quantified by plating on Hektoen agar and incubating the plates at $35^{\circ} \mathrm{C}$ for $24 \mathrm{~h}$. The total interfacial tension, free energy of the hydrophobic interaction $\left.\Delta \mathrm{G}^{\text {sws }} \mathrm{TOT}\right)$ and total free energy of adhesion $(\Delta \mathrm{G}$ adhesion) were determined. From a qualitative analysis of surface hydrophobicity, pears was considered hydrophobic, whereas the surfaces of 
bacteria cells were hydrophilic.Surface hydrophobicity by quantitative measurements of $\Delta G^{\text {sws }}>$ S. Enteritidis (30.806) and E. coli (74.432) cells were considered to be hydrophilic, whereas the surface of pears was considered to be hydrophobic (-52.998). Thermodynamic theory reports that adherence is a favorable process if the free energy per area unit is negative $\left(\Delta \mathrm{G}^{\text {adhesion }}<0\right)$, meaning that a spontaneous adhesion occurs. The process of S. Enteritidis $\left(1.0998 \mathrm{~mJ} / \mathrm{m}^{2}\right)$ and E. coli $\left(3.0983 \mathrm{~mJ} / \mathrm{m}^{2}\right)$ adherence are thermodynamically unfavorable on the surface studied $\left(\Delta \mathrm{G}^{\text {adhesion }}>0\right)$, yet adherence still occurred.This result may be due to microbiological aspects of adhesion rather than thermodynamic theory. The average roughness $(\mathrm{Ra})$ of the pears was $11.85 \pm 3.53 \mathrm{~nm}$. Adherence may be facilitated by an increased contact area between the microorganisms and the surface.The adhesion on pears slices was 6.65 e $7.00 \mathrm{log} \mathrm{CFU} / \mathrm{cm}^{2}$ for E. coli and S.Enteritidis, respectively. The results of roughness surface and adhesion process on pears indicated that it is a multifactorial process.

Palavras-Chave: Hydrophobicity, roughness, bacterial adhesion, vegetables Agência de Fomento: 